\title{
Evaluation of Hepatitis A Seroprevalance and Epidemiologic Data of Patients Applying to A Medical Faculty Hospital
}

\author{
Bir Tıp Fakültesi Hastanesine Bașvuran Hastalarda Hepatit A Seroprevalansı ve \\ Epidemiyolojik Verilerin Değerlendirilmesi
}

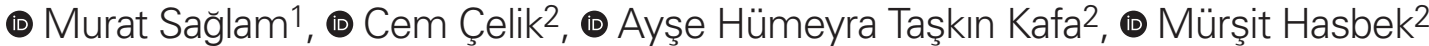 \\ ${ }^{1}$ Directorate of Public Health, Department of Environmental Health, Sivas, Turkey \\ 2 Sivas Cumhuriyet University Faculty of Medicine, Department of Medical Microbiology, Sivas, Turkey
}

\begin{abstract}
Objectives: Our study aims to determine seroprevalence of hepatitis A virus (HAV) in our region and to determine the prevalence change over years and to evaluate the effects of various factors on prevalence.

Materials and Methods: In our study, HAV diagnostic tests, which were studied by the ELISA method in the microbiology laboratory of our hospital for 10 years, were evaluated retrospectively from the laboratory information system. In the diagnosis of acute hepatitis, and anti-HAV immunoglobulin $\mathrm{M}(\mathrm{lgM})$ antibody was investigated in the blood, and anti-HAV IgG antibody was investigated for immunity to hepatitis A.

Results: Seropositivity of anti-HAV IgG was found to be $75.3 \%$, In comparison, while anti-HAV IgM positivity was found to be $2.7 \%$. While anti-HAV IgG and anti-HAV IgM positivity were found to be higher in individuals living outside the city center compared to individuals living in the city center, no significant difference was found between the genders.

Conclusion: Virus transmission has decreased in our region in recent years, and the encounter with the disease has shifted to advanced ages. This change increases the number of individuals susceptible to symptomatic infection. Therefore, hygiene and sanitation conditions should be monitored carefully, infrastructure should work adequately, and vaccination policies should be implemented when necessary.
\end{abstract}

Keywords: HAV seroprevalence, anti-HAV IgG, anti-HAV IgM
ÖZ

Amaç: $\mathrm{Bu}$ çalışmada yöremizde hepatit $A$ virüs (HAV) seroprevalansının belirlenmesi ve yıllar içinde prevalansta oluşan değişimin tespit edilerek, çeşitli faktörlerin prevalans üzerindeki etkilerinin değerlendirilmesi amaçlanmıştır.

Gereç ve Yöntemler: Çalışmamızda, 10 yıllık süreçte hastanemiz mikrobiyoloji laboratuvarında ELISA yöntemiyle çalışılan HAV tanı testleri laboratuvar bilgi sisteminden geriye dönük olarak değerlendirilmiştir. Akut hepatit tanısında kanda anti-HAV immünoglobulin $\mathrm{M}$ (lgM) antikor varlığı incelenirken, hepatit $\mathrm{A}^{\prime}$ ya karşı geliştirilen bağışıklık için ise kanda anti-HAV IgG antikor varlığı araştırılmıştır.

Bulgular: Çalışmada anti-HAV IgG seropozitifliği \%75,3 oranında bulunurken, anti-HAV IgM pozitifliği \%2,7 oranında bulunmuştur. Anti-HAV IgG ve anti-HAV IgM pozitiflikleri şehir merkezi dışında yaşayan bireylerde, şehir merkezinde yaşayan bireylere göre yüksek bulunurken, cinsiyetler arasında anlamlı bir farklılık saptanmamıştır. Sonuç: Yöremizde son yıllarda virüs bulaşı azalmış ve hastalıkla karşılaşma ileri yaşlara kaymıştır. Bu değişim semptomatik enfeksiyona yatkın duyarlı birey sayısını artırmaktadır. Bu nedenle hijyen ve sanitasyon koşulları dikkatli takip edilmeli, altyapı düzgün çalışmalı, gerekli durumlarda aşılama politikaları uygulanmalıdır. Anahtar Kelimeler: HAV seroprevalans, anti-HAV IgG, anti-HAV IgM

Sağlam M, Çelik C, Taşkın Kafa AH, Hasbek M. Evaluation of Hepatitis A Seroprevalance and Epidemiologic Data of Patients Applying to A Medical Faculty Hospital. Viral Hepat J. 2020;26:104-109. 


\section{Introduction}

Hepatitis is an inflammatory disease of the liver characterized by hepatocellular injury (1). The primary etiology of acute hepatitis is viral. Despite all advances, viral hepatitis is still a significant cause of mortality and morbidity worldwide (2). Hepatitis A Virus $(\mathrm{HAV})$ is a non-enveloped-RNA virus in the Picornaviridae family and is the most common cause of acute hepatitis worldwide. The disease has different forms, ranging from asymptomatic hepatitis to fulminant hepatitis, with no chronicity (3).

Fecal excretion in HAV infections is the primary source of the virus. $H A V$, primarily transmitted by the fecal-oral route, has different pathways (4). Accurate determination of the prevalence of hepatitis A infections becomes difficult due to the excess of asymptomatic patients and inadequate hospital discharge reports (5). In the definite and specific diagnosis of acute hepatitis $A$, the detection of immunoglobulin $M(\operatorname{lgM})$ antibodies developing against HAV is used. Anti-HAV lgG, which has protective and virus-neutralizing properties, is positive within a few weeks of infection and may remain positive for decades as an indicator of immunity (6).

The epidemiology of HAV varies greatly geographically. Hygiene conditions, access to clean water resources, and other socioeconomic conditions are the leading causes of geographical differences in the prevalence of HAV infection. Even if the improvement in these primary conditions reduces the incidence of $\mathrm{HAV}$, especially in developed countries, infection in developing countries still has a high incidence. Routine vaccination programs in countries also affect the epidemiology of HAV (7). In general, improvement in hygiene and sanitation conditions leads to a decrease in the number of cases, while seropositivity seems to shift to advanced ages (8).

In terms of HAV infection, our country is in the middle endemicity region and our country may have different rates in terms of seroprevalence in its regions and with other countries (6). To determine the preventive measures related to hepatitis $A$, a disease affecting large masses of the population, causing mortality as well as high morbidity, it is very essential to determine the prevalence of the disease in that society and monitor the prevalence change over the years (9). Our study aimed to determine seroprevalence of HAV in Sivas province, change in prevalence over the years, and evaluate the effects of factors on prevalence.

\section{Materials and Methods}

Our study was conducted at Sivas Cumhuriyet University Faculty of Medicine Hospital, a tertiary level education and research hospital with 1150 beds and 1544 polyclinics/day-patient capacity. In our study, the serology test results obtained from the samples sent from various departments to our laboratory between 2008-2017 were investigated retrospectively from the laboratory information system.

In these serology tests, the presence of anti-HAV IgM antibody in the blood was investigated in the diagnosis of acute hepatitis and the presence of anti-HAV IgG antibody in the blood was investigated for immunity to hepatitis $A$.

In order to detect anti-HAV antibodies in the serum within 2 hours at the latest, $3-5 \mathrm{~mL}$ blood samples taken from the EDTA tubes were separated into their sera by centrifugation in the laboratory. They were qualitatively analyzed according to the manufacturer's procedure using Chemiluminescent Microparticle Enzyme Immunological Test method with Architect i2000SR (Abbott Diagnostics, Illinois, USA) and Architect test kits (Abbott, Wiesbaden, Germany). Lipemic and hemolysed sera were not analyzed. Repeated results of the same patients for serology test parameters (lgG and $\operatorname{lgM}$ ) were not used in the study.

\section{Statistical Analysis}

The data obtained in our study were entered into SPSS (version 22.0 ), and the data was evaluated by using the chi-square test in $2 \times 2$ schemes. The Fisher's exact chi-square test was used when the hypothesis was not fulfilled, and the chi-square test was used in the multi-chamber schemes. The level of error was taken as $\mathrm{p}<0.05$.

\section{Results}

In this study, 21,578 anti-HAV test results of patients who applied to the outpatient clinics and clinics of Sivas Cumhuriyet University Application and Research Hospital between 2008 and 2017. The 21,578 anti-HAV test results from blood samples sent to the microbiology laboratory on suspicion of hepatitis and tested with the ELISA method were retrospectively examined in the patient records of the laboratory. The anti-HAV IgG test parameter was evaluated in 10,550 of these test results, and the anti-HAV IgM parameter was evaluated in terms of positivity and negativity in the remaining 11,028 test results. Anti-HAV IgG positivity was found to be $75.3 \%$ in all patients, and anti HAV IgM positivity was $2.7 \%$ in all patients (Table 1).

When HAV IgG and HAV IgM test results were evaluated in terms of gender, there was no statistically significant difference between the genders in terms of seropositivity ( $p>0.05$ ) (Table 2).

In our study, relatively low positivity rates were observed between 0-10 years, 11-20 years, and 21-30 years and seropositivity rates increased in older age groups. As a result, there is a difference between 0-10 years, 11-20 years, 21-30 years, and other age groups in terms of positivity rate. When anti-HAV lgG and anti HAV IgM positivity were evaluated according to age groups, the differences were significant $(p<0.05)$ (Table 3).

When anti-HAV IgG positivity was compared by the years, the difference was significant $(p<0.005)$. The lowest positivity rate was found in 2009 and 2010, and as the year increased, the positivity rate increased. The highest positive rate was observed in 2016 and 2017. When the anti-HAV IgM positivity rates were compared

\begin{tabular}{|l|l|l|l|l|}
\hline \multicolumn{4}{|l|}{ Table 1. Distribution of HAV diagnostic tests between 2008-2017 } \\
\hline \multirow{2}{*}{ Test parameter } & \multicolumn{2}{|l|}{ Result } \\
\cline { 2 - 4 } & Positive & Negative & \\
\hline \multirow{2}{*}{ Anti-HAV IgG } & $\mathrm{n}$ & 7,940 & 2,610 & 10,550 \\
\cline { 2 - 5 } & $\%$ & 75.3 & 24.7 & 100 \\
\hline \multirow{2}{*}{ Anti-HAV IgM } & $\mathrm{n}$ & 301 & 10,727 & 11,028 \\
\cline { 2 - 5 } & $\%$ & 2.7 & 97.3 & 100 \\
\hline \multirow{2}{*}{ Total } & $\mathrm{n}$ & - & - & 21,578 \\
\cline { 2 - 5 } & $\%$ & - & - & 100 \\
\hline HAV: Hepatitis A virüs, Ig: Immunoglobulin & \\
\hline
\end{tabular}


by years, the difference was also significant $(p<0.05)$. The highest positivity rates were observed in 2008, 2009, and 2011, while the positivity rate gradually decreased in the following years (Table 4).

When the anti-HAV IgG positivity of 9,212 patients, whose address information can be reached, were examined by location and when the anti-HAV IgM positivity of 9,665 patients was examined, it was seen that the positivity rates of those living outside the city center were higher than those living in the city center (Table 5).

\section{Discussion}

HAV infection is a common type of infectious hepatitis that is common all over the world, especially in developing countries. $\mathrm{HAV}$, which is spread via fecal-oral transmission, infects millions

\begin{tabular}{|l|l|l|l|}
\hline $\begin{array}{l}\text { Table 2. Comparison of anti-HAV IgM and anti-HAV IgG test positivity } \\
\text { between } 2008 \text { and } 2017 \text { by gender (\%) }\end{array}$ \\
\hline \multirow{2}{*}{ Test parameter } & Gender & Total \\
\cline { 2 - 3 } & Female & Male & \\
\hline Anti-HAV IgG & 75.9 & 74.6 & 75.3 \\
\hline Anti-HAV IgM & 2.6 & 2.8 & 2.7 \\
\hline HAV: Hepatitis A virüs, Ig: Immunoglobulin \\
\hline
\end{tabular}

\begin{tabular}{|c|c|c|c|}
\hline \multicolumn{2}{|l|}{ Age group } & \multicolumn{2}{|c|}{ Test parameter } \\
\hline & & $\lg G$ & $\lg M$ \\
\hline \multirow{2}{*}{$0-10$ age } & $\mathrm{n}$ & 668 & 108 \\
\hline & $\%$ & 36.5 & 4.9 \\
\hline \multirow{2}{*}{$11-20$ age } & $\mathrm{n}$ & 578 & 93 \\
\hline & $\%$ & 46.5 & 6.8 \\
\hline \multirow{2}{*}{$21-30$ age } & $\mathrm{n}$ & 1,269 & 50 \\
\hline & $\%$ & 64.7 & 3.1 \\
\hline \multirow{2}{*}{$31-40$ age } & $\mathrm{n}$ & 1,109 & 13 \\
\hline & $\%$ & 94.4 & 1.1 \\
\hline \multirow{2}{*}{$41-50$ age } & $\mathrm{n}$ & 1,135 & 9 \\
\hline & $\%$ & 99 & 0.8 \\
\hline \multirow{2}{*}{$51-60$ age } & $\mathrm{n}$ & 1,205 & 9 \\
\hline & $\%$ & 99.8 & 0.7 \\
\hline \multirow{2}{*}{$61-70$ age } & $\mathrm{n}$ & 1,046 & 7 \\
\hline & $\%$ & 99.2 & 0.6 \\
\hline \multirow{2}{*}{$71-80$ age } & $\mathrm{n}$ & 708 & 11 \\
\hline & $\%$ & 99.9 & 1.3 \\
\hline \multirow{2}{*}{$81-90$ age } & $\mathrm{n}$ & 213 & 1 \\
\hline & $\%$ & 98.6 & 0.3 \\
\hline \multirow{2}{*}{$91-100$ age } & $\mathrm{n}$ & 9 & 0 \\
\hline & $\%$ & 100 & 0 \\
\hline \multirow{2}{*}{ Total } & $\mathrm{n}$ & 7,940 & 301 \\
\hline & $\%$ & 75.3 & 2.7 \\
\hline
\end{tabular}

of people worldwide every year. Crowded living conditions, low income, and education, living in rural areas and slums, access to clean water are independent risk factors. Despite its low mortality, $\mathrm{HAV}$ infection is still a substantial public health problem as it causes outbreaks and loss of labor $(8,10)$.

Seroepidemiological data are of great importance to prevent common hepatitis A infections by developing effective prevention and vaccination strategies (11). Hepatitis A seroprevalence varies according to age groups, country, region, and hygiene/sanitation conditions. Therefore, it is more critical to monitor age-specific prevalence and change in prevalence over the years rather than the average prevalence (12).

Although Turkey may be considered as one of the moderate endemicity countries in terms of HAV infection, endemicity in their geographic area, age, and socioeconomic status may vary according to (10). In our study, the anti-HAV IgG positivity rate was

Table 4. Comparison of anti-HAV IgG and anti-HAV IgM test positivity between years 2008-2017 (\%) (IgG $n=10550, \lg M n=11028)$

\begin{tabular}{|c|c|c|c|}
\hline \multirow[t]{2}{*}{ Year } & & \multicolumn{2}{|c|}{ Test parameter } \\
\hline & & $\lg G$ & $\lg M$ \\
\hline \multirow{2}{*}{2008} & $n$ & 896 & 90 \\
\hline & $\%$ & 73.1 & 9.7 \\
\hline \multirow{2}{*}{2009} & $\mathrm{n}$ & 867 & 55 \\
\hline & $\%$ & 70.8 & 4.5 \\
\hline \multirow{2}{*}{2010} & $\mathrm{n}$ & 809 & 36 \\
\hline & $\%$ & 69.8 & 3.1 \\
\hline \multirow{2}{*}{2011} & $\mathrm{n}$ & 840 & 72 \\
\hline & $\%$ & 74.1 & 6.2 \\
\hline \multirow{2}{*}{2012} & $\mathrm{n}$ & 594 & 21 \\
\hline & $\%$ & 78.6 & 3 \\
\hline \multirow{2}{*}{2013} & $\mathrm{n}$ & 384 & 9 \\
\hline & $\%$ & 72.7 & 1.5 \\
\hline \multirow{2}{*}{2014} & $\mathrm{n}$ & 504 & 2 \\
\hline & $\%$ & 74.7 & 0.2 \\
\hline \multirow{2}{*}{2015} & $\mathrm{n}$ & 550 & 3 \\
\hline & $\%$ & 77 & 0.3 \\
\hline \multirow{2}{*}{2016} & $n$ & 714 & 4 \\
\hline & $\%$ & 78.5 & 0.3 \\
\hline \multirow{2}{*}{2017} & $\mathrm{n}$ & 1,782 & 9 \\
\hline & $\%$ & 80.2 & 0.4 \\
\hline \multirow{2}{*}{ Total } & $\mathrm{n}$ & 7,940 & 301 \\
\hline & $\%$ & 75.3 & 2.7 \\
\hline
\end{tabular}

Table 5. Comparison of anti-HAV IgG and anti-HAV IgM test positivity between $2008-2017$ by location

\begin{tabular}{|l|l|l|l|l|}
\hline Region & \multicolumn{2}{|l|}{ IgG Total patient/positive (\%) } & \multicolumn{2}{l|}{$\begin{array}{l}\text { IgM Total patient/positive } \\
\text { (\%) }\end{array}$} \\
\hline Center & $5,981 / 4,389$ & 73.4 & $5,992 / 144$ & 2.4 \\
\hline Rural & $3,231 / 2,577$ & 79.8 & $3,673 / 140$ & 3.8 \\
\hline HAV: Hepatitis A virüs, Ig: Immunoglobulin \\
\hline
\end{tabular}


found to be $75.3 \%$, and anti-HAV IgM positivity was $2.7 \%$ for all patients undergoing the HAV lgG test between 2008-2017. Our results are consistent with other studies in the literature. Several studies in the Central Anatolia region have reported anti-HAV IgG antibodies between $77 \%$ and $81 \%(13,14)$. Seropositivity was found to be $69.7 \%$ in Afyonkarahisar and $78.8 \%$ in Çanakkale $(15,16)$. In a study conducted in Rize from the Black Sea region, seropositivity was $75 \%$ (17). In a study conducted in Batman, southeast of the country, IgG antibody positivity was $93.9 \%$ (18). In a retrospective screening performed in Malatya, anti-HAV IgG seropositivity was found to be $74.4 \%$ (19). In Hatay, in the south of the country, seropositivity for the $\operatorname{lgG}$ antibody was $81.1 \%$ in 2007 (20). In some studies, it has been reported that the rate of seropositivity tends to decrease in our country (13). There was a significant decrease in the seroprevalence of HAV in Adana between 1998 and 2009 (21). In the general population study conducted by Poyraz et al. (22), in our province, anti-HAV IgG seropositivity was found to be $91 \%$ for all patients. When the study of Poyraz et al. (22), in our city was compared with our study, the significant decrease in anti-HAV lgG seropositivity appears to be an indicator of decreased virus circulation due to improvement in hygiene and sanitation conditions and socioeconomic conditions. In a retrospective study in Malatya, anti-HAV IgM positivity was reported to be $1.3 \%$ (19). In a study conducted in Konya, anti-HAV IgM positivity was $2.89 \%$, whereas, in a study involving children and adults in Kırşehir, anti-HAV IgM positivity was $0.5 \%(14,23)$. Similar rates have been reported in other studies reported from our country $(17,24,25)$. Rates ranging between 0.3 and up to $40 \%$ have been reported for anti-HAV IgM positivity from different geographic regions of the world $(26,27,28,29)$.

When anti-HAV IgG seropositivity was compared during the 10 years, the lowest rate was found in 2009 and 2010, and the highest rate was seen in 2016 and 2017. In our study, we obtained a low seropositivity rate in 2009 and 2010. We think that this low rate will be due to two reasons: the high rate of asymptomatic hepatitis A infection especially before the age of 6 and the inability to detect outbreaks from the asymptomatic transmission chain created by children who are prone to infection in crowded places such as nursery, kindergarten, and school. It was determined that seropositivity increased continuously in 2017 and reached its highest rate in 2017. This continuous rising in seropositivity is thought to be due to increase in individuals applying hospital because of symptomatic disease, the contribution of viral contact to adolescents and young adults from the early childhood due to the improvement in hygiene and sanitation conditions, and the contribution of hepatitis A vaccine, which has been added to routine vaccine program as of 2012.

In our study, when the anti-HAV IgM positivity was compared by years, the difference was found to be significant $(p<0.05)$. While the highest positivity was observed in 2008, 2009, and 2011 and the positivity rate decreased as the years increased, anti-HAV IgM positivity decreased sharply as of 2012 and reached its lowest rate for 2014. This situation is thought to be related to the increase in the number of seropositive children due to inclusion of hepatitis $A$ vaccine in the routine vaccination program as of September 2012, improvement in access to clean water and sanitation, and decrease in the number of family members as a result of improvement in socioeconomic conditions over the years. Studies in Israel and the United States report that vaccination of young children significantly reduces the incidence of HAV in all age groups $(30,31)$.

In our study, when we examined the distribution of anti-HAV lgG seroprevalence according to age groups, $36.5 \%$ to $100 \%$ were determined according to age groups within the range between 0 and 100 years of age (Table 3). In a study conducted in Diyarbakır, anti-HAV IgG seropositivity was found to be higher compared to our study results in terms of age groups (25). In a previous study conducted in Ankara, seropositivity was found 33.9\% between 0-19 years of age and over $90 \%$ in all age groups over 30 years of age (13). In a study conducted in Istanbul, it was determined that while seropositivity in the $0-10$ age group was $21 \%$, it was $19 \%$ in the 11-20 age group. It was also reported in the same study that seropositivity was balanced in both groups in the 21-30 age group (50\%) and it reached up to $81 \%$ after 30 years of age (32). Seropositivity, which was 55\% in the $20-29$ age group in Izmir, was reported to be over $90 \%$ after 40 years of age (33). In a previous study was conducted in the Çanakkale province, HAV seropositivity was found to be $61.4 \%$ for $17-21$ years, while $96.3 \%$ over 52 years (16). In our study, while the lowest seropositivity was seen in 0-10, $11-20,21-30$ age groups, respectively, it increased to more than $90 \%$ in the $31-40$ and later age groups and increased to $100 \%$. In the previous study in our province, seropositivity was above $90 \%$ at age 11 and after (22). While in our study, seropositivity was above $90 \%$ at age 31 and after. This difference indicates that the initial age of contracting HAV has shifted to older ages due to the improvement in the conditions of hygiene and sanitation, and socioeconomic level.

When the relationship between age groups and anti-HAV IgM positivity was examined in our study, the highest positivity rate was seen in 0-10, 11-20, 21-30 age groups in terms of age groups. At age 31 and over, the positivity rate decreases with age $(p<0.05)$. In our study, although the rate of acute HAV decreased gradually in the age groups, the high positivity rate in the 10-20 age group can be attributed to the contribution of viral contact to adolescents and young adults from early childhood due to the improvement in hygiene and sanitation conditions. Also, the hepatitis A vaccine given since 2012 is thought to have caused a lower anti-HAV IgM positivity rate in the $0-10$ age group compared to the 11-20 age group.

In the previous study conducted in our city, anti-HAV IgM positivity rates for the age groups 3-10 and 11-20 years were found to be $7.2 \%$ and $0.8 \%$, respectively, and $0 \%$ for subsequent age groups (22). When we compare this study with our study, it is seen that IgM positivity was found to be high in the 0-10 age group in the previous study, whereas in our study, IgM positivity reached the highest rate in the 11-20 age group. This suggests that the age of contracting HAV has shifted to advanced ages due to the reasons mentioned earlier. This change may lead to an increase in the number of adult individuals susceptible to symptomatic infection in the future.

In our study, no significant difference was found between the genders similar to the literature $(p>0.05)$. Worldwide prevalence studies show that anti-HAV IgG and IgM seropositivity are similar between genders $(26,29,34,35)$. In the study conducted by Poyraz et al. (22), in our province, anti-HAV lgG seropositivity was found 
to be $89.1 \%$ and $92.7 \%$, and anti-HAV IgM positivity was $1 \%$ and $1.4 \%$ in males and females, respectively. In a study conducted in Iğdır with patients aged 0-18 years, the rate of acute hepatitis A was $19.6 \%$ in females and $17.0 \%$ in males, and this difference was not significant (36). Other studies from our country have also shown that anti-HAV IgG and IgM seropositivity do not show a significant difference between genders $(16,23,25,37)$.

Anti-HAV IgG and IgM seropositivity were higher in people living in rural areas for all age groups in our study $(p<0.05)$. In a study covering the years between 2011 and 2014 in Konya, anti-HAV IgG seropositivity was found to be significantly higher in rural patients compared to urban patients, and living in rural areas was identified as an independent risk factor for anti-HAV IgG positivity (38). In another study conducted in Konya, anti-HAV IgM positivity was found to be significantly higher in the periphery districts compared to the central districts. In this study, anti-HAV IgM positivity was found to be the lowest in Meram district with high socioeconomic status (14). In the studies reported from our country and other parts of the world, seropositivity was found to be lower in individuals living in city centers $(39,40)$. Seropositivity was higher in individuals living in rural areas than in individuals living in the city center. It is thought to be related to poor sanitation conditions, lack of sewage system low rate of chlorinated drinking water consumption, and to some socioeconomic conditions such as crowded families in rural areas.

\section{Conclusion}

In the last 20 years, improvement in socioeconomic and hygiene-sanitation conditions in our country and the world has led to changes in the epidemiological profile and pattern of hepatitis A. As is known, even in regions of a country, differences in the conditions as mentioned above create variations in prevalence. Therefore, epidemiological studies on the prevalence of HAV in any area will provide guide the prevention of outbreaks in that area, and the development of new prevention and vaccination strategies.

\section{Ethics}

Ethics Committee Approval: Ethics Committee approval was obtained from Sivas Cumhuriyet University Ethics Committee (approval number: 01/10, date: 01.01.2018).

Informed Consent: It was conducted in accordance with the Ethics Committee and approval procedures.

Peer-review: Externally peer-reviewed.

\section{Authorship Contributions}

Concept: C.Ç., M.S., Design: C.Ç., M.S., Data Collection or Processing: C.Ç., M.S., A.H.T.K, M.H., Analysis or Interpretation: C.Ç., M.S., A.H.T.K, M.H., Literature Search: C.Ç., M.S., Writing: C.Ç., M.S., A.H.T.K, M.H.

Conflict of Interest: The authors declare no conflict of interest.

Financial Disclosure: The authors declare that this study has not received any financial support.

\section{References}

1. Felek S. Karaciğer ve Safra Yolları Infeksiyonları. Felek S. (ed). Sistemik Infeksiyon Hastalıkları. Istanbul: Nobel Tıp Kitabevi; 2000; p. 195-212.
2. Yenen OŞ. Akut Viral Hepatitler. In: Willke Topçu A, Söyletir G, Doğanay M. (ed). Infeksiyon Hastalıkları ve Mikrobiyolojisi. Vol. I. Istanbul: Nobel Tip Kitabevleri; 2002; p. 820-834.

3. Matheny SC, Kingery JE. Hepatitis A. Am Fam Physician. 2012;86:1027-1034.

4. Fiore AE. Hepatitis A transmitted by a food. Clin Infect Dis. 2004;38:705-715.

5. Bell BP, Wasley A, Feinstone SM. Hepatitis A Virus. In: Mandell GL, Bennett JE, Dolin R. (ed). Principles and practice of infectious diseases. 7th ed. Philadelphia: Churchill Livingstone; 2010; p. 2367-2387

6. Balkan II. Hepatit A Virüs Enfeksiyonu Klinik ve Yönetimi. In: Güner $\mathrm{R}$ ve Tabak F. (ed). Viral Hepatit 2018. 1 st ed. İstanbul: İstanbul Tıp Kitabevleri; 2018; p. 131-145.

7. Tosun S. Hepatit A Virüs Enfeksiyonu. In: Tabak F. ve Tosun S. (ed). Viral Hepatit 2013. 1 st ed. Istanbul: Istanbul Tıp Kitabevi; 2013; p. $215-246$

8. Mıstık R. Türkiye'de Hepatit A Virüs Enfeksiyonunun Epidemiyolojisi. In: Güner R ve Tabak F. (ed). Viral Hepatit 2018. 1 st ed. Istanbul: Istanbul Tip Kitabevleri; 2018; p. 1-12.

9. Curry MP, Chopra S. Acute Viral Hepatitis. In: Mandell GL, Bennett JE, Dolin R. (ed). Principles and practice of infectious diseases. 6th ed. Philadelphia: Churchill Livingstone; 2005; p. 1426-1440.

10. Yoldaş Ö, Bulut A, Altındiş M. The Current Approach of Hepatitis A Infections Viral Hepat J. 2012;18:81-86.

11. Shapiro CN, Coleman PJ, McQuillan GM, Alter MJ, Margolis HS. Epidemiology of hepatitis A: seroepidemiology and risk groups in the USA. Vaccine. 1992;10(Suppl 1):S59-S62.

12. Dökmetaş I. HAV enfeksiyonunun epidemiyolojisi ve patogenezi. In: Tabak, F, Balık I, Tekeli E. (ed). Viral Hepatit 2007. 1 st ed. Ankara: Viral Hepatitle Savaşım Derneği, 2007; p. 52-60.

13. Türker K, Balcı E, Batı S, Hasçuhadar M, Savaş E. In Our Country, the Changing Epidemiology of Hepatitis A Infection. Türk Mikrobiyol Cem Derg. 2011;41:143-148.

14. Kalem F, Erayman B, Yüksekkaya Ş, Kara F. The Seroepidemiology of Hepatitis A in Konya. Viral Hepat J. 2013;19:19-22.

15. Aşçı Z, Akgün $S$, Keşli R, Demirtürk N. Seroprevalence rates of Hepatitis $A$ virus in different age groups in the province of Afyonkarahisar. Göztepe Tıp Derg. 2014;29:94-98.

16. Arabacı F, Oldaçay M. The Seroprevalance of Hepatitis A in Different Age Groups and Hepatitis A Incidence in Acute Hepatitis Cases in The Canakkale Province. J Pediatr Inf. 2009;3:58-61.

17. Ertürk A, Çopur Çiçek, A, Cüre E, Akdoğan RA, Öztürk Ç. Seroprevalence of Hepatitis A in Rize Province and Different Adult Age Groups. Viral Hepat J. 2013;19:85-88.

18. Demirpençe Ö, Ișık Tezcan S, Değirmen E, Mert D, Gümüș A, Çelen MK. Seroprevalence of HAV, HBV, HCV and HIV in People Admitted to Batman State Hospital. Viral Hepat J. 2012;18:6-10.

19. Duman Y, Tekerekoğlu MS, Ay S, Serindağ A. (2017). Seroprevalence of Hepatitis A Virus in Inonu University Medical Faculty Hospital, 2015. Medicine Science. 2017;6:233-235.

20. Turhan E, Çetin M. The Seroprevalence of Viral Hepatitis A in Patients Who Had Consulted at Mustafa Kemal University of Medicine Faculty. Viral Hepat J. 2007;12:30-34.

21. Alhan E, Kozanoğlu B, Tümgör G, Çelik Ü, Yaman A, Bozdemir N. Epidemiological shift of hepatitis A in central Adana, Turkey. Turk J Gastroenterol. 2014;25 (Suppl 1):S6-S8.

22. Poyraz Ö, Sümer H, Öztop $Y$, Saygı G, Sümer Z. Sivas yöresinde genel toplumda Hepatit $A, B$ ve $C$ virüs belirleyicilerinin araştırılması. Turkish Journal Infection. 1995; 9:175-178.

23. Demir T, Turan M. Seroprevalence Rates of Hepatitis A Virus in Different Age Groups in the Province of Kırşehir and a Review of the Literature. Viral Hepat J. 2015;21:72-75. 
24. Yanık K, Akbal AU, Erdil M, Karadağ A, Eroğlu C, Günaydın M. Evaluation of the Prevalence of Hepatitis A in Samsun Vicinity. Viral Hepat J. 2015;21:23-7.

25. Temiz H, Özbek E, Toprak SF, Onur A, Ertuğrul S. Hepatitis A seroprevalence in patients who admitted to a training and research hospital in Southeast Anatolia. Dicle Med J. 2015; 42:485-489.

26. Asaei S, Ziyaeyan M, Moeini M, Jamalidogust M, Behzadi MA Seroprevalence of Hepatitis A and E Virus Infections Among Healthy Population in Shiraz, Southern Iran. Jundishapur J Microbiol. 2015;8:e19311.

27. Waheed-uz-Zaman T, Hussain AB, Hussain T, Anwar M, Ghani E, Asad-ullah. Hepatitis A virus infection -- shifting epidemiology. J Coll Physicians Surg Pak. 2006;16:15-18.

28. Lee A, Lim HS, Nam CM, Song SM, Yoon, HR, Lee KR. An epidemiological analysis of hepatitis $A$ virus serologic markers during the recent four years in Korea. Korean $\mathrm{J}$ Lab Med. 2009;29:563-569.

29. Pereira S, Linhares I, Neves AF, Almeida A. Hepatitis A Immunity in the District of Aveiro (Portugal): An Eleven-Year Surveillance Study (2002-2012) Viruses. 2014; 6:1336-1345.

30. Wasley A, Samandari T, Bell B. Incidence of hepatitis A in the United States in the era of vaccination. JAMA. 2015;294:194-201.

31. Chodick G, Green MS, Heymann AD, Rosenmann L, Shalev V. The shifting epidemiology of hepatitis A following routine childhood immunization program in Israel. Prev Med. 2007;45:386-391.

32. Alıcı Ö, Ağalar C, Yazıcılar HA. Hepatitis A Seroprevalence in Patients who Admitted to Training and Research Hospital in Istanbul. Viral Hepat J. 2013;19:110-114.
33. Kalfaoğlu H, Zeytinoğlu A, Öcek ZA. Hepatitis A Virus and Hepatitis E Virus Seroprevalence in Izmir. Flora. 2017;22:17-28.

34. Almuneef MA, Memish ZA, Balkhy HH, Qahtani M, Alotaibi B, Hajeer A, Qasim L, Knawy BA. Epidemiologic shift in the prevalence of Hepatitis A virus in Saudi Arabia: A case for routine Hepatitis A vaccination. Vaccine. 2006;24:5599-5603.

35. Karimi A, Mortazaei S, Moradi MT. High Prevalence of Symptomatic Hepatitis A Infection in Rural Area of Chaharmahal VA Bakhtiari Province, Iran. J Clin Diagn Res. 2015;9:1-3.

36. Arvas G, Kaya B, Berktaş M. The seroprevalance of Acute Hepatitis A in 0-18 Age Group Children who Applied to Iğdır State Hospital. J Pediatr Inf. 2011;5:129-131.

37. Iraz M, Gültepe B, Doymaz MZ. Seroprevalance of Hepatitis A in The Adult Age Groups. Abant Med J. 2015;4:54-58.

38. Özden HT. Hepatitis A seroprevalence in patients with chronic viral hepatitis in Konya, Turkey. Eur J Gastroenterol Hepatol.2016;28:333-337.

39. Cho HC, Paik SW, Kim YJ, Choi MS, Lee JH, Koh KC, Yoo BC, Son HJ, Kim SW. Seroprevalence of anti-HAV among patients with chronic viral liver disease. World J Gastroenterol. 2011;17:236241.

40. Sahin AM, Tekin A, Basmacı C, Uzun Kes N, Sönmez E. Hepatitis a seropositivity and characteristics among healthcare workers in a training and research hospital in Istanbul Medical Science and Discovery. 2016;3:296-300. 